\title{
Upper Carboniferous (Late Pennsylvanian) microfossils from the Wandel Sea Basin, Peary Land, eastern North Greenland
}

\begin{abstract}
Allen A. Petryk
The following account identifies and discusses the microfauna, and microflora from samples of Upper Carboniferous limestone collected from Hellefiskefjord in eastern Peary Land (fig. 4) by J. C. Troelsen during 1949 when a member of the Danish Peary Land Expedition (1947-1950). The samples were obtained from a section of limestones and shales which, as far as currently known, comprises the basal unit in the Hellefiskefjord area of the Wandel Sea Sedimentary Basin (Peel et al., 1974). The age of the samples is considered to be Late Pennsylvanian (Late Virgilian?), confirming the suggestion made by Troelsen (1950) on the basis of the occurrence of Triticites.

The name Wandel Sea Basin was proposed by Dawes \& Soper (1973) for an extensive series of Carboniferous to Tertiary sediments preserved as outliers in eastern North Greenland. The deposits overlie folded and eroded mainly Lower Palaeozoic strata of the North Greenland and East Greenland fold belts with major unconformity and provide an upper age limit for the main phases of orogenic activity in these geosynclines.

In the Amdrup Land-Holm Land area, some $300 \mathrm{~km}$ to the south-east, the oldest known strata in the Wandel Sea Basin are Lower Carboniferous clastics somewhat older than the late Upper Carboniferous calcareous sequence at Hellefiskefjord (see summary in Dawes, 1976). However, the lateral extension of units in the Peary Land part of the basin is so poorly known that it is currently difficult to evaluate the stratigraphic or structural significance of this difference.

A summary of the Wandel Sea Basin sequence in eastern Peary Land is given by Peel et al. (1974). The Carboniferous-Permian section at Hellefiskefjord is divided into a lower unit of at least $80 \mathrm{~m}$ of fusulinid limestone, violet shales and shaly limestone, and an upper unit of at least $230 \mathrm{~m}$ of brown-weathering grey, thin-bedded limestone. The Late Pennsylvanian microfauna and microflora discussed here were obtained from the lower unit. The upper unit contains a rich fauna of brachiopods and other fossils indicating a Lower Permian age (Stehli in Dawes, 1976).
\end{abstract}

\section{Identifications and stratigraphic locations}

The basal unit in the section measured by Troelsen in Hellefiskefjord is a basic sill intruded into folded Silurian sediments (section height $0-c .10 \mathrm{~m}$ ). Samples in the overlying Carboniferous are referred to a datum in a thin violet shale about $25 \mathrm{~cm}$ in thickness at a section height of $c .12 \mathrm{~m}$. 
Sample 171

$75-100 \mathrm{~cm}$ under the violet shale, section height $c .11 \mathrm{~m}$.

Larger and smaller foraminiferids

Triticites sp. A.

indet, fusulinid (cf. Pseudofusulinella)

bradyinid or globivalvulinid

cf. Climacammina sp.

Syzrania sp.

Tuberitina bulbacea Galloway \& Harlton, 1928

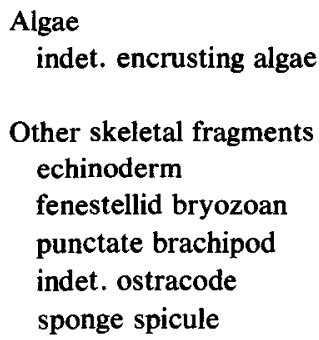

Sample 182

$35 \mathrm{~cm}$ under the violet shale, section height $c .11 .65 \mathrm{~m}$.

Larger and smaller foraminiferids

Triticites sp. B

Syzrania sp.

Pseudofusulinella sp.

Millerella sp.

Globivalvulina sp.

Eotuberitina sp.

Bradyina sp.

Tetrataxis group T. conica Ehrenberg, 1843

Climacammina sp.

Other skeletal fragments

bryozoan

ostracode

\section{Sample 175}

Calcareous lens in the violet shale, section height $12 \mathrm{~m}$.

Larger and smaller foraminiferids

Triticites sp. C.

indet. fusulinid

Globivalvulina sp.

Tetrataxis group T. conica Ehrenberg, 1843

cf. Climacammina sp.

Millerella sp.

Tuberitina bulbacea Galloway \& Harlton, 1928

\author{
Algae \\ Spaeroporella sp. \\ cf. Cuneiphycus and Stacheia sp. \\ indet. algae \\ Osagia sp. (algal-foraminiferid colony) \\ cf. Tubiphytes \\ Other skeletal fragments \\ echinoderm \\ fenestellid bryozoan \\ Tentaculites? sp.
}


Sample 172

$10 \mathrm{~cm}$ above the violet shale, section height $c .12 .2 \mathrm{~m}$.

Larger and smaller foraminiferids

Triticites sp. A ?

indet. fusulinid

$?$ cornuspirid sp. $=($ Apterrinella $?$ sp. in Toomey, 1972, p. 295)

Globivalvulina group G. bulboides (Brady) Tuberitina bulbacea Galloway \& Harlton, 1928 1876

Tetrataxis group $T$. conica Ehrenberg, 1843

Algae

indet. tetrataxid

indet. algae

cf. Millerella sp.

Osagia sp.

Syzrania bella Reitinger, 1950

Brunsia sp.

Glomospira sp.

Other skeletal fragments

bryozoan

\section{Sample 187}

$5 \mathrm{~m}$ above the violet shale, section height $c .17 \mathrm{~m}$.

Larger and smaller foraminiferids

Pseudofusulinella sp.

Apterrinella ? sp.

Globivalvulina sp.

Tuberitina sp. or Palaeocancellus sp.

Climacammina sp.

Syzrania sp.

Other skeletal fragments

? endothyrid

bryozoan

ostracode

\section{Sample 179}

$17 \mathrm{~m}$ above the violet shale, section height $c .29 \mathrm{~m}$.

Larger and smaller foraminiferids

Triticites sp.

Monotaximoides sp.

cf. Ozawainella sp.

cf. Schubertella sp. (primitive form)

Apterrinella? sp.

? Pseudofusulinella sp.

Bradyina sp.

Globivalvulina sp.

Tetrataxis group $T$. conica Ehrenberg, 1843

indet. tetrataxid

Climacammina group C. moelleri Reitlinger, 1950

Tuberitina sp.

Cornuspira sp.

Glomospira sp.

Algae

indet. algae

Osagia sp.

Syzrania sp.

Other skeletal fragments echinoderm bryozoan ostracode coral 


\section{Sample 183}

$19 \mathrm{~m}$ above the violet shale, section height $c .31 \mathrm{~m}$.

Larger and smaller foraminiferids

Triticites sp. B ?

Syzrania sp.

Apterrinella ? sp.

Eotuberitina sp. (?foraminiferid)
Other skeletal fragments bryozoan gastropod ostracode ? trilobite spine

\section{Sample 180}

$20.5 \mathrm{~m}$ above the violet shale, section height c. $32.5 \mathrm{~m}$.

Larger and smaller foraminiferids crushed schwagerinids (large proloculus)

Tuberitina sp. (?foraminiferid)
Other skeletal fragments brachiopod ostracode echinoderm

\section{Sample 181}

$22 \mathrm{~m}$ above the violet shale, section height $c .34 \mathrm{~m}$.

Larger and smaller foraminiferids

Triticites sp. B ? (large proloculus, thick spirotheca)

cf. Ozawainella sp.

? Globivalvulina sp.

Syzrania sp.

Apterrinella ? sp.

Tuberitina sp. (?foraminiferid)

\author{
Algae \\ indet. dasyclad alga \\ Other skeletal fragments \\ fenestellid bryozoan \\ bryozoan \\ gastropod \\ sponge spicules
}

\section{Sample 178}

Loose lying, upper part of the sequence.

Larger and smaller foraminiferids

Triticites sp. D?

Climacammina sp.

Apterrinella ? sp.

Glomospira sp.
Syzrania sp.

Tuberitina bulbacea Galloway \& Harlton, 1928

(?foraminiferid)

Algae

Osagia sp. 


\section{Discussion}

About twenty taxa of larger and smaller foraminiferids and six taxa of algae are present in the thin sections prepared from the ten samples from Hellefiskefjord. Of the larger foraminiferids, the Schwagerininae, Triticites spp. predominate whereas the Fusulininae, Pseudofusulinella spp. and others, are less common. This alone is indicative of the zone of Triticites which is of Missourian-Virgilian (Upper Pennsylvanian) age in terms of the south-western North America standard, and Gzhel'ian-Orenburgian (Upper Carboniferous) in terms of the Ural and Perm sections of eastern Europe. The considerable degree of septal folding and conspicuous chomata in the Hellefiskefjord Triticites is believed to be an evolutionary phase common to Upper Pennsylvanian members of the American Triticites group (Dunbar, 1963, p. 33, 37). Furthermore, the presence of Pseudofusulinella and Schuchertella suggests a Late Pennsylvanian, possibly Late Virgilian age (Dunbar, 1963, p. 42; Ross, 1967, p. 1345).

The fusulinid assemblage from Hellefiskefjord is younger than that reported by Thomson (1961), from Ward Hunt Island, off the northern tip of Ellesmere Island in the Canadian Arctic, which was assigned a Middle Pennsylvanian (Middle Desmoinesian) age. It is older than the Lower Permian (Artinskian) assemblage from the Belcher Channel Formation of Grinnell Peninsula, Devon Island (about $800 \mathrm{~km}$ south-west of Ward Hunt Island) described by Thorsteinsson (1960).

The assemblage of larger and smaller foraminiferids and algae is rather similar to that of the Virgilian Leavenworth Limestone of the Midcontinent region of the United States detailed by Toomey $(1969,1972)$ but it apparently lacks some of the endothyrids and algae.

All the Fusulinidae are cosmopolitan and are equated with the Midcontinent-Andean Realm, except for Pseudofusulinella which is apparently of the Eurasian-Arctic Realm (Ross, 1967).

Sedimentologically, several carbonate microfacies are discernible; angular quartz silt is locally abundant. Much of the fauna contains agglutinated, attached multilocular, and encrusting tubular smaller foraminiferids, associated with a diverse algal assemblage. These elements and the fact that the skeletal and floral fragments appear to be considerably diminuted, suggest shallow marine shelf sedimentation.

In conclusion, the fusulinid-bearing lower unit of Troelsen's section in Hellefiskefjord may, in part, be coeval with the Belcher Channel Formation around Canon and Greely Fiords, Eureka Upland, central-western Ellesmere Island (Thorsteinsson, in Thorsteinsson \& Tozer, 1970).

\section{Acknowledgements}

Stratigraphical information on the Hellefiskefjord section was taken from J. C. Troelsen's unpublished diaries, P. R. Dawes supplied data on the geological and stratigraphical framework and J. S. Peel suggested several modifications to the text.

\section{References}

Dawes, P. R. 1976: Precambrian to Tertiary of northern Greenland. In Escher, A. \& Watt, W. S. (edit.) Geology of Greenland, 248-303. Copenhagen: Geol. Surv. Greenland. 
Dawes, P. R. \& Soper, N. J. 1973: Pre-Quaternary history of North Greenland. In Pitcher, M. G. (edit.) Arctic Geology. Mem. Am. Ass. Petrol. Geol. 19, 117-134.

Dunbar, C. O. 1963: Trends of evolution in American fusulines. In Von Koenigswald, G. H. et al. (edit.) Evolutionary trends in Foraminifera, 26-44. Amsterdam: Elsevier Publ.

Peel, J. S., Dawes, P. R. \& Troelsen, J. C. 1974: Notes on some Lower Palaeozoic to Tertiary faunas from eastern North Greenland. Rapp. Grønlands geol. Unders. 65, 18-23.

Ross, C. A. 1967: Development of fusulinid (Foraminiferida) faunal realms. J. Paleontol. 41, 1341-1354.

Thompson, M. L. 1961: Pennsylvanian fusulinids from Ward Hunt Island.J. Paleontol. 35, 1130-1141.

Thorsteinsson, R. 1960: Permian fusulinids of Grinnell Peninsula. In Harker, P. \& Thorsteinsson, R. (edit.) Permian rocks and faunas of Grinnell Peninsula, Arctic Archipelago. Mem. geol. Surv. Can. 309, 21-38.

Thorsteinsson, R. \& Tozer, E. T. 1970: Geology of the Arctic Archipelago. In Douglas, R. J. W. (edit.) Geology and economic minerals of Canada. Econ. Geol. Rep. geol. Surv. Can. 1, 548-590.

Toomey, D. F. 1969: The biota of the Pennsylvanian (Virgilian) Leavenworth Limestone, midcontinent region. Pt. 2: Distribution of algae. J. Paleontol. 43, 1313-1330.

Toomey, D. F. 1972: The biota of the Pennsylvanian (Virgilian) Leavenworth Limestone, midcontinent region. Pt. 3: Distribution of calcareous Foraminifera. J. Paleontol. 46, 276-298.

Troelsen, J. [C.] 1950: Geology. In Winther, P. C. et al. A preliminary account of the Danish Pearyland Expedition, 1948-9. Arctic 3, 6-8.

Québec Department of Natural Resources, Energy Branch, Exploration Division, 1305 Chemin Ste-Foy, Québec G1S $4 N 5$,

Canada.

\title{
A reconnaissance of Quaternary deposits in northern Greenland
}

\author{
Anker Weidick
}

The main aim of the 1976 field work was an investigation of the extent of Quaternary deposits in the central part of Olrik Fjord, north of Thule Air Base, North-West Greenland. In addition, other localities were visited across northern Greenland to locate and collect samples for $\mathrm{C}^{14}$ dating in order to supplement the hitherto sparce evidence of Holocene deglaciation and uplift of this region, i.e. at Narssârssuk, south of Thule Air Base, central Hall Land, J. P. Koch Fjord, and the delta of Børglum Elv in Peary Land (fig. 8).

\section{Olrik Fjord}

Olrik Fjord is $80 \mathrm{~km}$ long. At its western junction with Hvalsund (Ikerssuaq) it is $8 \mathrm{~km}$ wide whereas its greatest part forms a $3-4 \mathrm{~km}$ wide channel penetrating plateau landscapes with surfaces at $800-1000 \mathrm{~m}$ above sea level. There are few earlier investigations of the Quater- 